\title{
TÄDI MAALIST TÄDI MAALIKS
}

Võib ilmselt liialdamata öelda, et iga eestlane teab, kes on tädi Maali. Eks ikka lihtsakoeline, lihtsa mõtlemisega inimene, kelle teadmised ei ulatu kodutanumast kaugemale. See kujund vallutas pikaks ajaks avaliku keelekasutuse, tõrjudes tagaplaanile kõik teised sama tähendusega väljendusvõimalused. Tädi Maali tõusuaeg jääb uue aastatuhande algusesse. Võib arvata, et otsest vajadust selle fraasi järele ei olnud, sest mõiste TAGASIHOIDLIKU HARIDUSE JA AMETIGA LIHTINIMENE märkimiseks on eesti keeles juba hulk nimetusi: reainimene, tavainimene, argiinimene, tosinainimene, massiinimene.

Võimalik, et 2000. aastate algul, kui käimas olid Euroopa Liiduga ühinemise läbirääkimised ja taheti väljendada vajadust teha see selgeks igas vanuses, iga erialaga Eesti kodanikule, ei tundunud ükski neist sõnadest küllalt lööv. Kui president Lennart Meri ütles oma kõnes, et Euroopa Liiduga ühinemisest tuleb rääkida nii, et ka tädi Maali aru saaks, saigi osava mõistestaja kasutatud väljend peagi üldtuntuks kui lihtkodaniku ühisnimetaja. Kasutussageduse tõttu on kujundi tähendusmaht avardunud, hõlmates mitte ainult lihtsakoelise mõtlemisega ja eluga mitte kursis olevat inimest, vaid ka (tehniliste) teadmisteta, võhiklikku inimest. Tädi Maali kujund rajaneb teadmisel, et tädi on keegi võõras või tundmatu vanem naine, ning stereotüüpsel eeldusel, et vanemad naised ei ole suure tõenäosusega kuigi mõtlemis- ega arutlusvõimelised. Tähendust 'ajast maha jäänu', nt Usun, et näeksin selles välja nagu täielik tädi, võimendab vanamoeline pärisnimi fraasi peasõnana. Eesnimi Maali ei ole praegu populaarne, seda ei ole kuigi tihti tüdrukutele pandud juba üle poole sajandi. 2017. aasta 1. jaanuari seisuga on nimi Maali 20 naisel. Maali on populaarsuselt 1784. naisenimi. ${ }^{1}$ Need asjaolud annavadki sisu tädi Maalile: arutleb tädi Maali tasemel; tunnen end tädi Maalina.

\section{Kui vana on tädi Maali?}

Millal tädi Maali hakkas eristuma muunimelistest tädidest ja üldistus kujundiks ning millal seda väljendit on eesti keeles esmakordselt kasutatud, sellele ei olegi nii lihtne jälile saada. Üldiselt kiputakse ekslikult arvama, et see väljend on president Lennart Meri fantaasia vili ning alguse saanud tema ametlikest kõnedest ja intervjuudest, eriti seoses Eesti pürgimisega Euroopa Liitu ja rahva teavitamise vajadusega: ... sest mis tahes uuendus saab edukas olla ainult tingimusel, kui seda toetab rahvas, tädi Maali kaasa arvatud. ${ }^{2}$ Tavaliselt nii ongi, et kui arvamusliider vm tuntud inimene kasutab eredat, mahlakat kujundit, siis on see õige pea väga paljude keelekasutajate suus ja sule all. Nii läks ka väljendiga tädi Maali ja ka näiteks hüüatusega Tule taevas appi!, millega Lennart Meri tavatses vahel absurdset olukorda illustreerida. Eriti populaarseks sai tädi Maali poliitikute keelepruugis ja meedias. Mõne harva erandiga jõudis see tarbe- ja poliitika-

${ }^{1}$ Nimede statistika. http://www.stat.ee/ public/apps/nimed/ (25. V 2017).

${ }^{2}$ Euroliit tuleb teha tädi Maalile arusaadavaks. Vabariigi Presidendi intervjuu ajalehele Postimees 28. märtsil 2001; K. Õim, A. Õim, P. Muikku-Werner, Uudne metafoorne keelend: kas laen või diakroonilise arengu tulemus? - Lähivõrdlusi. Lähivertailuja 2013, nr 23, lk 428-456; https://et.wikipedia. org/wiki/T\%C3\%A4di_Maali (10. V 2017). 
tekstides ülekasutatud kujund ka nõudlikumasse teksti, nt käsitöömeister Aino Praakli on lausa pealkirjastanud oma elulooraamatu „Tädi Maali jutud” (Tartu, 2010). 2001. a 18. jaanuari Riigikogu stenogrammis seisab: Ühelt poolt pole me kõik suutnud Euroopa Liiduga liitumise tähendust $k a$ tädi Maalile, nagu president armastab ütelda, lahti seletada. Juba sama aasta maikuus kirjutab sotsioloog Mari Uba: Kriis ja tädi Maali on mõisted, mis on vabastanud paljud seletamatust painest. Miski oli nagu keelel, mis lõpuks valla pääses. Ühiskonnas aset leidvatele protsessidele leiti ühtäkki sildid (Kantar Emor 10. V 2001). Rein Sikk alustab Eesti Päevalehes tädi Maali regulaarse kirjanurgaga.

Ent tädi Maali autor ei ole siiski Lennart Meri. Rahvaliku (maa)tädina oli see tuntud kindlasti palju varem. Guugeldamisega võib leida varasemat kasutust nt Eesti Ekspressist ja Postimehest juba 1990. aastatel, st palju varem, kui meie president seda kasutas: Kui tädi Maali oma emisega (jumal teab, kuidas) ikkagi Su kliinikusse ilmub, kas ajad ta uksest välja? (Eesti Ekspress 8. V 1994); Tädi Maali Uugametsast või Nikolai Narvast ei suudaks seda niikuinii nii vaadata, et labasus neid tegudele ei kihutaks (A. Walden, Postimees 10. XII 1996); Tädi Maali pole sedavõrd tuntud inimene, et ta eraelu lugeja huvi võiks köita (E. Vetemaa, Postimees 23. IX 1998); Tavaline investor ehk kuulus Tädi Maali ei teegi ilmselt vahet, mis erinevus on Eesti riigi võlakirjal ja Hüvitusfondi võlakirjal (V. Lokk, Äripäev 29. X 1998); Tädi Maali mudel pensionisüsteemis (Äripäev 22. II 2000).

Riigikogu stenogrammides on tädi Maalit mainitud 31 korda enne Lennart Meri Euroopa Liidu teemalisi sõnavõtte (1997 - V. Raudnask, 1998 - A. Mölder, E. Parder, 2001 - M. Laar, A. Liiv, M. Treial, V. Rumessen, T. Toomsalu jpt): Seda enam, et kell on juba nii kaugel, et tädi Maali on kindlasti oma kanakoivad Keskturult kätte saanud (V. Raudnask, 10. IX 1997); Uno Mereste kolleegina on küsinud mitu korda, et kas see tädi Maali kohta ka käib (A. Mölder, 17. VI 1998).

\section{Kus on tädi Maali juured?}

Võimalik, et kujundi juured on meie ilukirjanduses. Kirjanduslikult eredaima tädi Maali leiab lookesest „Pärandusega tädi", mis ilmus ajalehes Ühistegelised Uudised ( $\mathrm{nr}$ 6, 6. II 1925). Ka Olivia Saare lühijutus „Vanaisa juubelipirukas" (Täheke 1975, nr 9) on üheks tegelaseks tädi Maali, Lehte Hainsalu kirjutab tädi Maalist oma ahelromaanis „Kellakuuljad” (Eesti Raamat, 2001) jpt. Kirjanduslikud Maalid on sümpaatsed, tagasihoidlikud, heatahtlikud, kellelegi olemiseks vajalikud vanemad naised. Need iseloomulikud omadused sobinuksid tädi Maali kujundi allikaks. Ent paistab, et üldistatud kujundit sellest siiski ei sündinud või kui sündiski, siis see kuigivõrd tuntuks ei saanud.

Teine võimalus on, et kujundi tekkes on teiste keelte mõjutusi, nagu see viimasel paaril aastakümnel eesti keeles sageli ette tuleb, otsetõlkeid kohtame ju hulgi.

Soome fraseoloogiauurija professor Pirkko Muikku-Werner juhatas lahkelt väljendi Pihtiputaan mummo ${ }^{3}$ juurde, mis on tähenduse poolest tädi Maalile kõige lähemal. Erinevalt meie tädi Maalist on selle sünniaeg ja autorgi hästi teada. Väljendi esmakasutaja on ajakirjanik ja Tampere ülikooli ajakirjandusõppejõud Allan Liuhala, kes kirjutab 1960. aastate alguses: Pitää kirjoittaa niin, että Pihtiputaan mummokin se ymmärtää. ${ }^{4}$

Pihtiputaan mummo kujundimehhanism rajaneb kohanimel Pihtipudas (sellenimeline vald asub Lääne-Soome läänis Kesk-Soome maakonnas) ja teadmisel, et mummo on vanem naine (kas a) vanaema või b) vanamemm, mutt, eit), ning eeldusel, et vanemad naised

\footnotetext{
3 https://fi.wikipedia.org/wiki/Pihtiputaan mummo (10. V 2017).

4 J. Pietilä, Allan Liuhala - lehtimies. Edita, 2008.
} 
ei ole tõenäoliselt kuigi ärksad: Samaa kännykkää pystyy käyttämään niin Pihtiputaan mummo kuin naapurin insinööriopiskelijakin. Apple kehittää systeeminsä Pihtiputaan mummolle, koska ihminen on yksinkertainen olento (P. Muikku-Werneri näited, tema sõnutsi on see tähendus üldlevinud). Selle nimetuse keeleliseks aluseks on rühma inimeste (vanaemade) tunnuslike omaduste metonüümiline ülekanne: vanaema seondub soome rahvusluse, lihtsa inimese, eriti maanaise tublidusega. Fraasile Pihtiputaan mummo on omased ka positiivsed konnotatsioonid, eriti silmas pidades mummo tähendust 'vanaema'. Pihtipudase vallas on 1994. a alates vanaemadele välja antud Pihtiputaan mummo tiitlit.

Ehkki tädi Maali kujund ei tekita kuigivõrd negatiivseid assotsiatsoone, ei ole see ka sedavõrd positiivne, et oleks soome keele eeskujul aset leidnud kujundi sihtvaldkonna sisese ülekande muutus. Eesti keeles on pigem kujundit ära kasutatud kattevarjuks, et õigustada asjade lihtsustatud käsitlusi ja rõhutada lihtsate lahenduste otstarbekust: ... poliitikud on tädi Maali armsa kujundi ära kaaperdanud ning ehitanud selle peale ühiskonna lihtsustatud mudeli (I. Tarand, Põhjarannik 23. VIII 2011).

Mis puutub aga auväärsete eakate naiste ja meeste tiitlitesse, siis on meilgi (nähtavasti Soome eeskujul) nende panuse tunnustusena ühiskonna arengusse oma austavad nimetused. Riigi tasandil on selleks külm ja kiretu Aasta Vanaema (ja/või Aasta Vanaisa), maakonna tasandil siiski soojem ja emotsionaalsem Memm (ja/või Taat): Järjekorras juba kuues Viru Memme ja Viru Taadi valimise pidu peetakse Roela lauluväljakul (Virumaa Teataja 21. VII 2005). Kujundliku nimetusena tädi Maali oma sisu poolest selleks ei kvalifitseeru.

Soome keeles on veel teinegi kujundlik keelend, mis tähistab mõistet KONSERVATIIVNE, UUENDUSKARTLIK INIMENE. See on kukkahattutäti 'lihtsakoeline, konservatiivne, vähese vastutusvõimega, moraalitsev inimene, eriti naisametnik': $N y t$ kukkahattutädit haluavat kieltää tupakan mainostuksen. ${ }^{5}$ Selle kujundliku liitsõna halvustav, negatiivne konnotatsioon $^{6}$ on säilinud ka otsetõlkena levival lillekübaratädil. Google’i otsimootoriga leiab seda eestikeelsetest foorumitest: Soome "lillekübaratädid" ehk sealne lastekaitsemaffia võtab neilt lapsed ära esimeste nädalate jooksul (Perekool 20. VIII 2016).

Eesti keeles katavad seda mõistet praegu adjektiiv tädilik ja substantiiv tädi: Kergelt sõrmevibutavalt tädilik lugu, inimeselt kes sinisilmselt näib uskuvat, et kui siin kirjutada, siis inimesed muudavad oma harjumusi (Äripäeva veebikommentaar 22. III 2016); Lapsi tuleb kaitsta väärkohtlemise eest, kuid tädilik ülehooldamine on noorte arengule ja kodanikuks kasvamisele kahjulik (Õpetajate Leht 23. I 2009); Ministeeriumi tädid arvavad, et noored võiksid vastuvõtu ootel ise esineda.... (Virumaa Teataja 26. VI 2004). Kui tekib vajadus erksama kujundi järele, siis see ka leitakse, kas laenatakse teistest keeltest, taaselustatakse mõni unustatud vana või luuakse päris uus.

\section{ASTA ÕIM, EPP EHASALU}

${ }^{5}$ Urbaani Sanakirja Com. http://urbaanisanakirja.com/word/kukkahattutati/57088/ (10. V 2017).

${ }^{6}$ R. Klem ettin en, Kukkahattu kukkistelee.-Kielikello 2014, nr 3. http://www.kielikello.fi/index.php? mid=2\&pid=11\&aid=2659 (10. V 2017). 